\title{
Bioactivity Analysis of Curcuminoids from Turmeric using On-line Screening HPLC-ABTS
}

\author{
Sun Do Choi*
}

\section{On-line Screening HPLC-ABTS를 이용한 강황으로부터 Curcuminoids의 생물활성 분석}

\author{
최 선 도*
}

Received: 16 April 2013 / Accepted: 25 April 2013 / Published Online: 30 September 2013

(C) The Korean Society for Applied Biological Chemistry 2013

\begin{abstract}
Free radical scavengers in the bisdemethoxycurcumin (BDMC), demethoxycurcumin (DMC) and curcumin of turmeric (Curcuma longa) were screened, identified, quantified and isolation using coupled off-line-2,2'-azino-bis(3-ethylbenzthiazoline6-sulphonic acid) (ABTS) and on-line screening high-performance liquid chromatography (HPLC)-ABTS assay. There was a very small margin of error between the off-line-ABTS method and the on-line screening HPLC-ABTS method.
\end{abstract}

Keywords isolation · on-line screening high-performance liquid chromatography $\cdot$ simultaneous analysis $\cdot$ turmeric

강황(Curcuma longa 이하 turmeric)은 생약재로 널리 이용되고 식품첨가물로 잘 알려졌으며 카레의 주원료인 향신료 성분이다 (Zhang, 등 2008; Choi, 2009). 또한 전통적으로 염증, 항산화, 항돌연변이성, 간 해독, 항암 및 혈소판 응집억제 등의 효능이 보고되었다(Singh 등, 2010; Zhao 등, 2011). 본 연구에서는 curcuminoids의 curcumin (MW=368), demethoxycurcumin (DMC, $\mathrm{MW}=338$ ), bisdemethoxycurcumin (BDMC, MW=308)를 용매 추출하여(Lee 등, 2012), 빠른 생리활성 평가를 on-line screening high-performance liquid chromatography (HPLC)-2,2'-azino-bis (3-ethylbenzthiazoline-6-sulphonic acid) (ABTS) assay로 확인 하였고 off-line-assay와 비교 하여 활성이 우수한 curcumin (MW=

\section{S. D. Choi}

Department of Chemical Engineering, Kangwon National University Samcheok Campus, Gangwon-do, Samcheok, 245-711, Republic of Korea

*Corresponding author (S. D. Choi: sun1215@kangwon.ac.kr)
368)을 고순도로 분리를 하였다. 이러한 on-line screening HPLC-ABTS assay을 사용한 빠른 활성물질의 탐색은 선택적으 로 유용성분의 고순도 획득 및 동시 분리-분석을 통해 효율적 인 활성소재 확보를 위한 선택적 추출 및 분리의 가능성을 확 인할 수 있었다. 하지만 강황으로부터 on-line screening HPLCABTS assay를 적용한 빠른 생리활성 평가의 연구는 매우 미미 한 실정이다. 따라서 본 연구는 상용공정의 기초데이터를 실험 적으로 구하여 비교하였다. 연구에 사용된 강황(turmeric) 시료 는 중국 지방에서 재배되었으며 2012년 3월 (주)서룡상사/영천 현대약업사에서 수입 및 구매하여 한국한의학연구원 한의신약개 발그룹에서 엄선된 시료를 사용하였다. 표준시료인 curcumin은 Sigma-Aldrich Co. (C1386, USA)에서 구입하였다. 시료의 균일 성을 위하여 수분조절 용기(desiccator)에 보관하여 사용하였고 모든 시료들은 주입하기 전에 막 여과지(PVDF $0.2 \mu \mathrm{m}$, Waters co)를 이용하여 여과를 하였다. 용매는 HPLC급( $99.9 \%)$ 으로 methanol, acetonitrile은 J.T. Baker Co. (USA)과 TFA은 Sigma-Aldrich Co. (USA) 용액을 사용하였으며 물은 3차 증류 수(Waters, USA)를 사용하였다. Radical scavenging 활성분석을 위하여 ABTS 시험법을 사용했으며, 사용된 시약은 2,2-azinobis(3-ethylbenzothiazoline-6-sulfonic acid (ABTS, $\mathrm{C}_{18} \mathrm{H}_{24} \mathrm{~N}_{6} \mathrm{~S}_{4}$ ) 와 potassium per-sulfate를 사용하여 완전히 녹인 후, $\mathrm{ABTS}$ 시약과 충분히 교반 후 차광시켰다. 제조된 용액은 $1 \mathrm{~L}$ 갈색병 에 넣고 하루 정도 라디칼의 안정성을 위해 어두운 곳에서 보 관한 뒤 사용하였다(Lee 등, 2012). 추출은 일정한 상온 $\left(25^{\circ} \mathrm{C}\right)$ 에서 수행 하였으며 건조 분쇄된 시료는 입자를 체 거름(30 $\mu \mathrm{m})$ 으로 분별하여 시료로 사용하였고 이때 수분 함유량은 $10.5 \%$ 였다. 이후, 강황 건조분말 $3 \mathrm{~g}$ 을 $250 \mathrm{~mL}$ 비이커에 추출 용매 $100 \%$ 메탄올을 각각 $100 \mathrm{~mL}$ 를 첨가하여 침적방법 (dipping)을 적용하여 추출시간 $1 \sim 5 \mathrm{~h}$ 동안 시행하여 물질의 변 화를 확인하였다. Curcumin의 표준시료 $2 \mathrm{mg}$ 을 고순도 메탄올 


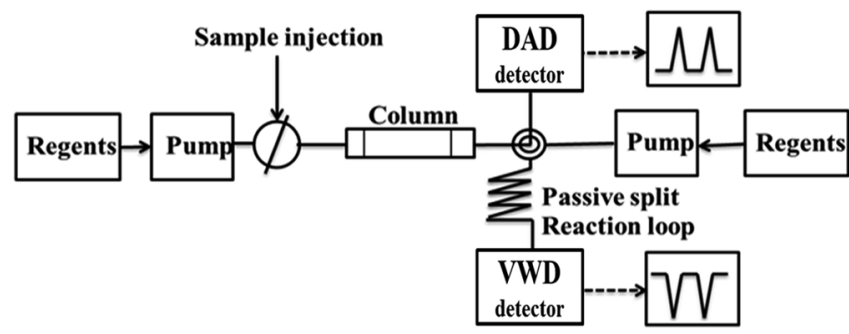

Fig. 1 Schematic of on-line screening HPLC-ABTS system.
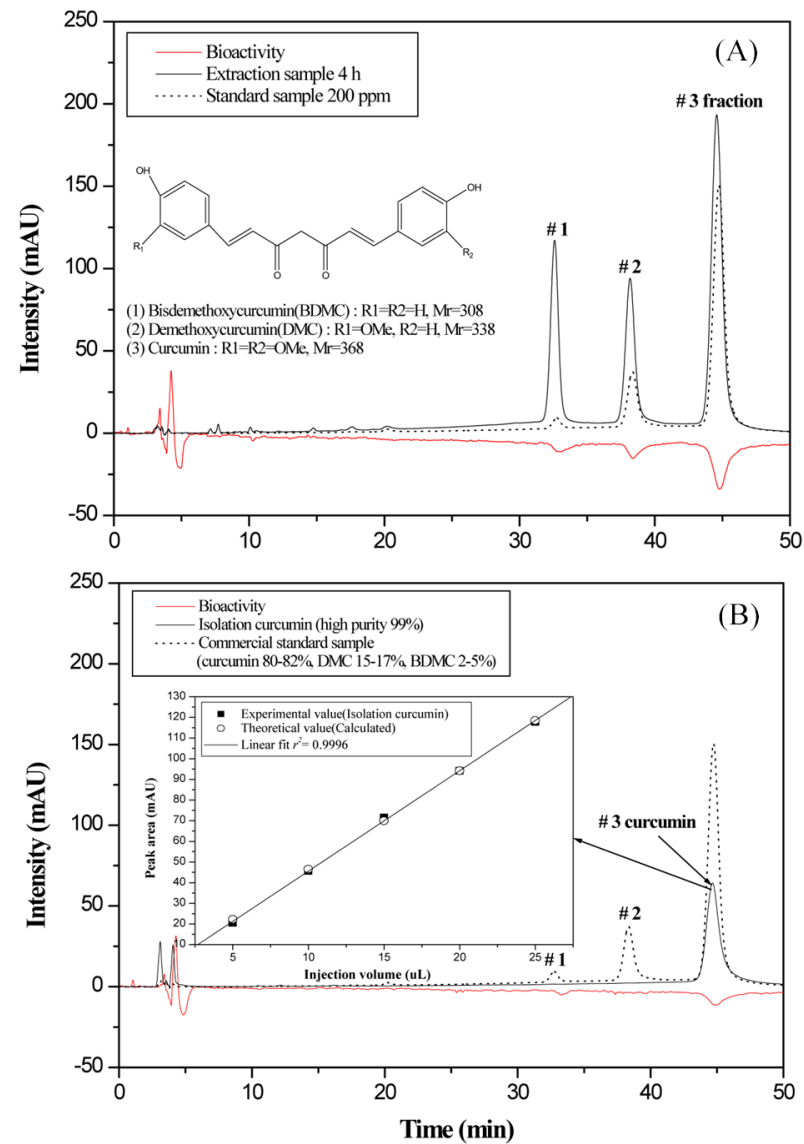

Fig. 2 Analysis of curcuminoids from turmeric using on-line screening HPLC-ABTS ((A) injection volume: $10 \mu \mathrm{L}$, (B) injection volume: $15 \mu \mathrm{L}$, positive UV wavelength $420 \mathrm{~nm}$, negative wavelength: $730 \mathrm{~nm}$, mobile phase (A: $0.1 \%$ TFA in water $60 \%$, B: acetonitrile $40 \%$, run time $50 \mathrm{~min}$, flow rate: $1 \mathrm{~mL} / \mathrm{min}$, ABTS-flow rate: $0.5 \mathrm{~mL} / \mathrm{min}$ ).

$10 \mathrm{~mL}$ 를 취하여 $200 \mathrm{ppm}$ 의 표준원액을 제조하였다. HPLC시스 템으로는 Dionex Co.의 3000 pump와 injector는 $10 \mu \mathrm{L}$ sample loop (Dionex, ID $\times$ L $0.18 \times 550 \mathrm{~mm}$ Viper $550 \mathrm{~mm}$, USA)가 연결되었고, 데이터 처리는 Dionex Co.의 PC에 설치된 Chromeleon data acquisition system (Dionex version 7.0.1.272) 과 HPLC-DAD를 사용하여 정량 및 정성분석을 하였다. 분석 에 사용된 컬럼은 $\left(\mathrm{RS}\right.$-tech $\left.4.6 \times 250 \mathrm{~mm}, 5 \mu \mathrm{m}, \mathrm{C}_{18}, \mathrm{Korea}\right)$ 와 유속은 $1.0 \mathrm{~mL} / \mathrm{min}$, 주입부피는 $10 \mu \mathrm{L}$, 컬럼오븐 온도 $40^{\circ} \mathrm{C}$ 로 고정하였다. UV 검출기(DAD)의 파장범위를 $200-450 \mathrm{~nm}$ 로 적 용하여 $420 \mathrm{~nm}$ 로 검출하였고 생물활성은 $734 \mathrm{~nm}$ 로 나타내었다.
Table 1 Identification and amount of extraction time using on-line screening HPLC-ABTS

\begin{tabular}{clcccr}
\hline $\begin{array}{c}\text { Extraction } \\
\text { Solvent } \\
(\%)\end{array}$ & $\begin{array}{c}\text { Compounds } \\
\text { name }\end{array}$ & $\begin{array}{c}t_{R} \\
(\mathrm{~min})\end{array}$ & $\begin{array}{c}\text { Yield } \\
(\%)\end{array}$ & $\begin{array}{c}\text { Total } \\
\text { extraction } \\
\text { amount }(\mathrm{g})\end{array}$ & $\begin{array}{c}\text { Amount } \\
(\mu \mathrm{g} / \mathrm{mL})\end{array}$ \\
\hline \multirow{3}{*}{$1 \mathrm{~h}$} & BDMC & 32.563 & & & 67.819 \\
& DMC & 38.107 & 6.547 & 0.196 & 66.532 \\
& Curcumin & 44.417 & & & 170.751 \\
\hline \multirow{3}{*}{$2 \mathrm{~h}$} & BDMC & 32.540 & & & 76.696 \\
& DMC & 38.087 & 6.733 & 0.202 & 71.629 \\
& Curcumin & 44.453 & & & 184.058 \\
\hline \multirow{3}{*}{$3 \mathrm{~h}$} & BDMC & 32.510 & & & 80.895 \\
& DMC & 38.083 & 7.190 & 0.216 & 76.714 \\
& Curcumin & 44.477 & & & 199.190 \\
\hline \multirow{3}{*}{$4 \mathrm{~h}$} & BDMC & 32.590 & & & 83.171 \\
& DMC & 38.170 & 7.533 & 0.226 & 78.971 \\
& Curcumin & 44.577 & & & 201.657 \\
\hline \multirow{3}{*}{$5 \mathrm{~h}$} & BDMC & 32.670 & & & 87.188 \\
& DMC & 38.253 & 7.567 & 0.227 & 81.658 \\
& Curcumin & 44.667 & & & 209.572 \\
\hline
\end{tabular}

이동상은 이성분계 $\mathrm{A}: \mathrm{H}_{2} \mathrm{O} / \mathrm{TFA}(99.9 / 0.1 \mathrm{v} / \mathrm{v})$, B: Acetonitrile $(100 \mathrm{v} / \mathrm{v})$ 을 사용하여 $(\mathrm{A}: \mathrm{B} 60: 40 \mathrm{v} / \mathrm{v})$ 으로 $50 \mathrm{~min}$ 동안 일정용 매조성법으로 실험하였다. Fig. 1에서는 on-line screening HPLC-ABTS assay 시스템을 나타내었다. 이러한 생물활성 screening 시스템을 이용한 동시분석과 추출 확인이 탁월한 online screening HPLC-ABTS assay를 적용한 크로마토그램 결과 를 Fig. 2(A, B)에서 보여주고 있다. 특히 선행연구(Lee 등, 2013)를 기초로 한 이동상 조성에서 $\mathrm{BDMC}, \mathrm{DMC}$ 및 curcumin의 빠른 생물활성 능력을 screening 할 수 있었고 이중 에서 curcumin의 생물 활성이 peak area (negative mAU: 45.0284)로 제일 높았다. 이때 물질 사이의 각 체류시간 $\left(t_{R}\right)$ 은 curcumin $44.417 \mathrm{~min}, \mathrm{DMC} 38.107 \mathrm{~min}$, 및 $\mathrm{BDMC} 32.563$ $\min$ 이였고 분리도가 1.5 이하로 낮았다(Fig. 2(a)). 또한 생물활 성이 우수한 curcumin(\# 3)을 선택적으로 분획하여 순도(99\%) 의 고순도 물질을 얻을 수 있었다(Jiang 등, 2012). 이러한 순 수 물질은 이론값=계산값(Theoretical value)과 실험값 (Experimental value)으로 상호 비교하여 실험값이 $r^{2}=0.999$ 이 상으로 이론값과 매우 잘 일치되는 것을 확인 할 수 있었다(Fig. 2(B)). Table 1에서는 추출시간에 따른 curcuminoids의 BDMC (\# 1), DMC (\# 2) 및 curcumin (\# 3)의 추출 효율을 나타내 었다. 이때, curcuminoids의 추출 수율은 $4 \mathrm{~h}$ 일때 $7.533 \%$ 로 $5 \mathrm{~h}$ 일때 $7.567 \%$ 보다 오차 범위 내에서 확인되었고 변화가 작았다. 이때 최적의 추출 시간은 $4 \mathrm{~h}$ 이었으며 선행연구 결과와 일치 하 였다(Lee 등, 2013). 이러한 연구경향은 추출시간에 따른 생물 활성을 on-line ABTS-assay와 off-line ABTS-assay를 비교하여 나타내었다(Table 2). 추출시간 증가에 따른 on-line ABTSassay (peak area negative mAU)는 $5 \mathrm{~h} 45.5460>4 \mathrm{~h} 45.0284$ $>3$ h 41.9803>2 h 36.3800>1 h 29.5831로 시간에 따라 증가하 였고, off-line ABTS-assay $\mathrm{IC}_{50}(\%)$ 은 $1 \mathrm{~h} 1.8984>2 \mathrm{~h} 1.6924$ $>3 \mathrm{~h} 1.6774>4 \mathrm{~h} 1.6272$ 로 활성이 증가되었다. 하지만 $5 \mathrm{~h}$ 이후 $\mathrm{IC}_{50}(\%)$ 이 1.7297 로 감소 하는 경향을 보여 최적의 생물활성 추 출 시간은 $4 \mathrm{~h}$ 임을 확인 할 수 있었다(Inoue 등 2011). 따라서 
Table 2 Comparison of bioactivity by on-line-ABTS assay and off-line-ABTS assay

\begin{tabular}{|c|c|c|c|c|c|c|}
\hline \multirow{2}{*}{$\begin{array}{c}\text { Extraction } \\
\text { Solvent }(\%)\end{array}$} & \multirow{2}{*}{$\begin{array}{c}\text { Compounds } \\
\text { name }\end{array}$} & \multicolumn{3}{|c|}{ On-line ABTS assay } & \multicolumn{2}{|c|}{ Off-line ABTS assay } \\
\hline & & $\begin{array}{l}\text { Peak area } \\
\text { (negative) }\end{array}$ & $\mathrm{SD}( \pm)$ & $\begin{array}{c}\text { Total } \\
\text { Peak area }\end{array}$ & $\mathrm{IC}_{50}(\%)$ & $\mathrm{SD}( \pm)$ \\
\hline \multirow{3}{*}{$1 \mathrm{~h}$} & BDMC & 2.5843 & 0.013 & & & \\
\hline & $\mathrm{DMC}$ & 5.7899 & 0.023 & 29.5831 & 1.8984 & 0.1134 \\
\hline & Curcumin & 21.2086 & 0.025 & & & \\
\hline \multirow{3}{*}{$2 \mathrm{~h}$} & BDMC & 3.7211 & 0.012 & & & \\
\hline & DMC & 6.2459 & 0.028 & 36.3800 & 1.6924 & 0.0840 \\
\hline & Curcumin & 26.4131 & 0.029 & & & \\
\hline \multirow{3}{*}{$3 \mathrm{~h}$} & BDMC & 4.8580 & 0.009 & & & \\
\hline & DMC & 6.7458 & 0.021 & 41.9803 & 1.6772 & 0.0590 \\
\hline & Curcumin & 30.3765 & 0.015 & & & \\
\hline \multirow{3}{*}{$4 \mathrm{~h}$} & BDMC & 5.3324 & 0.007 & & & \\
\hline & $\mathrm{DMC}$ & 7.5681 & 0.027 & 45.0284 & 1.6272 & 0.0667 \\
\hline & Curcumin & 32.1279 & 0.021 & & & \\
\hline \multirow{3}{*}{$5 \mathrm{~h}$} & BDMC & 5.8165 & 0.009 & & & \\
\hline & DMC & 7.3862 & 0.015 & 45.5460 & 1.7297 & 0.0599 \\
\hline & Curcumin & 32.3433 & 0.013 & & & \\
\hline
\end{tabular}

Data expressed mean $\pm \mathrm{SD}(\mathrm{n}=3)$

전 처리한 추출액에 포함된 강황으로부터 on-line screening HPLC-ABTS-assay를 이용한 생물활성을 빠르게 screening하여 탐색하고 최적의 추출조건을 실험적으로 모색 할 수 있었다.

\section{초 록}

강황(Curcuma longa)으로부터 bisdemethoxycurcumin (BDMC), demethoxycurcumin (DMC) 및 curcumin의 생물 활성을 offline-ABTS 측정법과 on-line screening high-performance liquid chromatography (HPLC)-ABTS 측정법을 적용한 빠른 스크리닝 을 통해 정량 및 성분 분리를 하였다. 이때, off-line-ABTS와 on-line screening HPLC-ABTS 비교는 미미한 오차를 보여주 었다.

Keywords 강황 - 동시분석 - 분리 - 온라인 스크리닝 HPLC

\section{References}

Choi HY (2009) Isolation and Identification of Antimicrobial Compound from Ulgeum (Curcuma longa L.) J Korean Soc Food Sci Nutr 38, $1202-9$.

Inoue K, Kitade M, Hino T, and Oka H (2011) Screening assay of angiotensin-converting enzyme inhibitory activity from complex natural colourants and foods using high-throughput LC-MS/MS. Food Chemistry 126, 1909-15.

Jiang JL, Jin XL, Su HZX, Qiao B, and Yuan YJ (2012) Identification of antitumor constituents in curcuminoids from Curcuma longa L. based on the composition-activity relationship. J Pharm Biomed Anal 70, 664-70.

Lee KJ, Liang C, Yang HJ, and Ma JY (2012) Rapid Identification of Homoorientin from Phyllostachys bambusoides Leaves by HPLC Online ABTS+ Screening Method. Yakhak Hoeji 56, 217-21.

Lee KJ, Ma JY, Kim YS, Kim DS, and Jin YZ (2012) Solid Phase Extraction (SPE) of Curcuminoids from Turmeric by Optimization Analytical Condition. $J$ of the Korea Academia Industrial cooperation Society 13, 4927-35.

Lee KJ, Kim YS, and Ma JY (2013) Separation and Identification of Curcuminoids from Asian Turmeric (Curcuma long L.) Using RP-HPLC and LC-MS. Asian Journal of Chemistry 25, 909-12.

Lee KJ, Choi SD, and Ma JY (2013) Phytochemical Analysis of Curcumin from Turmeric by RP-HPLC. Asian Journal of Chemistry 25, 995-8.

Singh G, Kapoor IPS, Singh P, Heluani CS, Lampasona MP, and Catalan CAN (2010) Comparative study of chemical composition and antioxidant activity of fresh and dry rhizomes of turmeric (Curcuma longa Linn.). Food Chem Toxicol 48, 1026-31.

Zhao XC, Zhang L, Yu HX, Sun Z, Lin XF, Tan C et al. (2011) Curcumin protects mouse neuroblastoma Neuro-2A cells against hydrogenperoxide-induced oxidative stress. Food Chemistry 129, 387-94.

Zhang JS, Guan J, Yang FQ, Liu HG, Cheng XJ, and Li SP (2008) Qualitative and quantitative analysis of four species of Curcuma rhizomes using twice development thin layer chromatography. J Pharm \& Bio Anal 48, 1024-8. 